\title{
GENDER IN SOCIAL MEDIA: SEMIOTIC STUDY OF GENDER CONSTRUCTION OF WOMEN IN INSTAGRAM ACCOUNT @MODUSKERAS POSTINGS MUHAMMADIYAH SURAKARTA UNIVERSITY
}

\author{
Dwi Bagus Nurrohman ${ }^{1, a)}$ \\ Yudha Wirawanda ${ }^{2}$ \\ ${ }^{1}$ Universitas Muhammadiyah Surakarta \\ ${ }^{2}$ Universitas Muhammadiyah Surakarta \\ a) Corresponding author: dwidwibagus@gmail.com
}

DOI:https://doi.org/10.18196/jkm.101010

Article Info

Article history:

Received 9 Jul 2018

Revised 18 Okt 2018

Accepted 19 Okt 2018

\section{ABSTRACT}

Instagram is one kind of social media that allows users to share photos to others. But not only regular photos that distributed by users, sometimes the photo contains sexuality. Instagram @ moduskeras account generally displays women as its object. This research with qualitative method aims to find out how gender constructions occur in social media Instagram by tracing the semiotic elements on images uploaded by @ moduskeras account. Using theories about Instagram as social media, gender constructions, gender bias in online media, and semiotics. Using Peirce's semiotic analysis that carries three elements: signs, objects, and interpretations. The sign will then be categorized into icon, index, and symbol. There are 10 images which become the object of studying how gender is constructed. Researcher saw that 10 pictures have several aspects of the sign that can show how women's gender is formed. The 10 images then inserted into four types of categorization: Objectivication of women's bodies, commercialization of women, women become objects of fetishism and being passive, and women have limits and imprisonment from the world. The result of this research is Instagram @ moduskeras account constructs women's gender based on patriarchal system which women can not be separated from sexuality and become the object of men.

Keywords: gender, construction, women, semiotic, instagram, male gaze

Instagram adalah satu jenis media sosial yang memungkinkan penggunanya berbagi foto kepada pengguna lain. Namun tak hanya sekedar foto biasa yang seringkali dibagikan pengguna instagram, kadangkala foto tersebut mengandung seksualitas seperti di dalam akun Instagram @moduskeras yang umumnya menampilkan perempuan sebagai objeknya. Penelitian dengan metode kualitatif ini bertujuan mengetahui bagaimana konstruksi gender terjadi dalam media sosial Instagram dengan menelusuri unsur-unsur semiotik dari berbagai gambar unggahan akun @moduskeras. Dengan menggunakan teori-teori media sosial, konstruksi gender, bias gender dalam media online, dan semiotika. Menggunakan analisis semiotika Charles Peirce yang mengusung tiga unsur, yaitu tanda, objek, dan interpretan. Tanda kemudian akan dikategorikan menjadi ikon, indeks dan simbol. Terdapat 10 gambar yang menjadi objek kajian bagaimana gender dikonstruksi. Peneliti melihat 10 gambar tersebut terdapat aspek-aspek tanda yang dapat menunjukkan bagaimana gender perempuan dibentuk. 10 gambar tersebut kemudian dimasukkan kedalam 4 macam kategorisasi yaitu: Objektivikasi tubuh perempuan, komersialisasi perempuan, perempuan menjadi objek fetishisme dan menjadi sosok pasif, serta perempuan memiliki batas dan terpenjara. Hasil penelitian ini adalah akun 
Instagram@moduskeras mengkonstruksi gender perempuan sesuai dengan paham patriarki yang membuat perempuan tidak bisa terlepas dari seksualitas dan menjadi objek dari laki-laki.

Kata kunci: gender, konstruksi, perempuan, semiotika, instagram, male gaze

\section{INTRODUCTION}

The newest development of the internet is social media, which spur the exchange of information to flow faster than mainstream media.Information can be accessed anywhere at anytime. Social media is understood as the latest form of new media development that makes easy for people to exchange information, share and network online so they can spread their own content, can be reproduced and viewable by millions of people for free (Zarella 2010). In social media, communicators can spread their messages in various forms such as images, video, audio, and text in virtual spaces where people connect to one integrated and combined network (Flew, 2004).Instagram is one type of social media that have many users. Data from Statista.com in December 2016, Instagram users are over 600 million people. On April of 2017, Instagram users touched the number 700 million people. Instagram be a social media application that is mandatory for people. In the site of instagram itself, it is written "We imagine a world more connected through photos" (www.instagram.com/about/faq), so it can be understood instagram is a social media that provides means of communication through photos where users can share moments and give respond to another photos uploaded by other users.

The features provided by instagram are used as entertainment by social media users. Generally, kind of uploads on Instagram are the moments of someone who wants to share to others, so that others can respond by giving like or comment (Kurniawati, 2016). Instagram gives the users freedom to upload and share the desired photos to the audience (Arif, 2017). But because of the widespread age of social media users, it raises a wide range of interests. One of them is uploading images that have adult genre. Sexuality is a product that sells for the sustainability of a media (Judhita, 2015). Seeing the status of women who had always been viewed as the sex object of men, the perception that women should appear and behave as sex objects is a necessity (Hariyanto, 2009). So many of the scattered images on instagram raise the theme of adult jokes by exploiting women as their visual message.Women are more dominant than men in becoming media objects, various forms of body and expression of women can be commodified by media holders to reap the benefits. In the research of Shaista Irsyad and Niroj Banerji (2012) entitled Gender as Social Construct in Margareth Atwood's Oryx and Crake explains that women's sexual commodities are always available for consumption and most of the audience are men, woman become suppressed or oppressed and male as oppressor. Laura Mulvey (1975) in her article "Visual Pleasure and Narrative Film" says that cinematography turns women into an object of male gaze, how women become a pleasing visual experience for men. Mulvey argues that cameras are representative of men who have an active side of view.

The high level of anonymity in social media makes users feel free in doing activities in the cyber space (Zubaidi, 2011). The anonymous account is not clear who the real user is, because it is mediated by technology. One such anonymous account is@moduskeras. The @moduskeras is an active Instagram accounts, which has 72 thousand followers. This account was established in October 2016, which can be seen from the date uploaded the content on Instagram for the first time. The @ moduskeras account is a public account, whose the contents are humorous usingwomen sensuality as its object. A lot of similar accounts@moduskeras featuring the same things, like @ betjanda, @ preman.duri, @ premankalem, @ unyil.jahat and many more. Rarely do the images they upload contain the male object, even if there is certainly not a whole body of men. This shows that women are still regarded as a very salable object. According to Gilman in Sue Thormam, 2000: 172 (in Judhita, 2015), men are market and demand while women are supply. Women become fabrication products that are disinvested from the body and re-applied in a fashion that makes them suitable to be exchanged among men through the media used. The @ moduskeras account is the subject of research because this account is quite active in uploading their content, with an average of 2 uploads per day, and this account has growing number of followers and this account seen by researcher is quite evident in showing women sensuality. 
To find out how gender construction occurs on @ moduskeras' postings, the study of signs is required. This is usually defined as semiotics (Budiman, 2011). The image is one form of human communication medium. Whereas communication can only occur when there is mean of sign, be it visual non-verbal or verbal, as disclosed by Charles Sanders Peirce (Fiske dalam Judhita, 2015). A sign according to Peirce is something that represents or stands for something else in some respects. Something is an interpretation and an object. Signs are physical or visual forms that are captured by

Page | 114 the human senses. Objects or reference of signs are the social contexts that are references of a sign or something to which a sign is pointed. Interpretation is the meaning that exists in the mind of a person against the object referred to by the sign(Vera,2015).

In previous research journal by Megaria Farnisari and Arif Sudrajat (2013) entitled Gender Bias in Korean Series Film Sungkyunkwan Scandal explains that the construction of patriarchal culture has a major impact on women portrayals in the film and it is mentioned that women are often shown helpless. The identity will be formed when women use makeup and appearance support. The similarity in this research is using Charles Sanders Peirce semiotics method. The difference with the research of Megaria and Sudrajat Arif is series film as the subject. The subject of this research is the images of @moduskeras account, while the object of this research is how the gender constructions of women in the picture. So, the main focus of this research is the gender constructions of women contained in the picture @moduskeras. With the aim of studying the gender construction of the uploaded images @ moduskeras it is hoped this research provides a new view in given message, how the messages and images affect each other. Because the traditional gender concept explains that gender is understood as a set of actions that tend to be expected from individuals based on the gender they have (Yulidya, 2014). The problem formulation in this research is how the construction of gender on Instagram @ moduskeras account upload. This research uses qualitative method with semiotic analysis approach from Charles Sanders Peirce.

\section{LITERATURE REVIEW}

\section{Instagram as Social Media}

Social media is understood as the latest form of new media development that makes it easy for people to exchange information, share and form online networks so they can spread their own content, can be reproduced and can be viewed by millions of people for free (Zarella, 2010). Another characteristic of social media is that it allows individuals to create public and semi-public profiles bounded by the system, articulate a list of other users with whom they share a connection, and can view and traverse connection lists created by others in the system (Boyd \& Elisson, 2008). Antony Mayfield in an e-book entitled "What Is Social Media" (2008) defined social media as a medium where users can easily participate, share and produce messages, including social networks, blogs, wikis / online encyclopedias, online forums, as well as virtual worlds (usually supported by avatars / $3 \mathrm{D}$ characters). Each type of social media has its own features in communication and information delivery, such as mobile connectivity, blogs, or even sharing videos and pictures (Boyd \& Elisson, 2008).

In the research by Dyah Ayu Puspitorini (2013) entitled Motive and Satisfaction of Instagram Use (Study of Gap between Motives and Satisfaction of Instagram Media Usage at Students of Muhammadiyah University of Surakarta Force 2013) explains that instagram is one form of social media that makes easy to share photographs, online video as well as social networking services that can be used to retrieve and share to their friends. Instagram also has features like sharing story, sharing a private message and providing a comment field on everyone's uploads. In Instagram Ebook (2017) described Instagram's latest feature is sharing GIF, live video, so the user can show what they are doing to his followers directly.

Social Media becomes a must-have means for people today.With all the features social media offers, causing a lot of information exchange that no longer sees place or time, be it positive or negative content. As far as searches have been done, researcher found the results of research that has a tangent point with the title raised in this study. One of them is a journal made by Anang Sugeng Cahyono (2016) with the title of Social Media Influence on Social Change Society in Indonesia. The results of the analysis have shown that there are practices that deviate from social norms in the use of social media. 


\section{Gender Contruction}

According to Berger and Luckmann (in Lay, 2018) social construction concept is defined as a social reality which constructed in the minds of people and perpetuated and reinforced in society through rituals of socialization and communication. Gender is a trait, a behavior, a role attached to men and women that occurs because of social construction that results in terms of masculinity and femininity. Because the traditional gender concept explains that gender is understood as a set of actions that tend to be expected from individuals based on the sex they have (Yulidya, 2014). In the journal Gender in Media Construction by Hariyanto (2009) explained that the definition of gender is the division of roles both the rights and obligations of both women and men based on determination of society or culture. Like, there is a belief that men are strong, rough, and rational, while women tend to be weak, gentle, and emotional.

Gender is not determined by God's nature, but a result of social construction and has a long history. The determination of the role, nature, and character of women and men can be exchanged, changing with the times, and having their own characteristics in each place. Thus, gender within society can be diverse and different. Gender differences do not matter when they do not cause injustice (Hariyanto, 2009).Laura Mulvey (in Karunianingsih, 2016) argues that cinematography shapes women into an object of gaze, how women become a pleasurable visual experience for men.In the media, the eye of the camera is always analogous to the eyes of men, women tend to adhere to the control of the male gaze. Mulvey (1989) argues that women are castrated human being, which causes women to be inferior to men because they do not have a penis. Men can realize their obsession and fantasy because of women. This makes women in a position that has no power over itself, but only become the object for the desire of men.

The researcher found a suitable categorization to examine how gender construction occurred in the upload images by @moduskeras. The researcher refers to Laura Mulvey's Visual and Other Pleasure book (1989). There are four categorizations to be used, namely: 1.) Objectivization of women's body 2.) Commercialization of women 3.) Women become the object of fetishism and being passive 4.) Women have limits and imprisonment from the world. Women are not considered as important as men, they only seen as object. Further, because women only seen by their sensuality and sexuality aspects, women always be commodified into profit. Their appearance also coupled by other signs which are considered as representation of men and became symbol that women can not stand by themselves without men. Women also has imaginary border which limits their role in certain social life.

Gender construction which is often featured in the media based on the label of masculinity and femininity, as found in the research of Shaista Irsyad and Niroj Banerji (2012) under the title Gender as Social Construct in Margareth Atwood's Oryx and Crake, discusses how gender in novels is built socially and culturally based construction of masculinity and femininity. In previous research on gender constructions, as Damayanti (2014) entitled Gender Construction in Visual Imagery of Textbooks for Basic Students. In the study, the method used was the method of text analysis and the results of his research found that the images contained gender inequalities. This research needs a gender construct theory, because to be able to find out how women are displayed on the upload image of @moduskeras.

\section{Gender Bias in Online Media}

Gender bias is one of major social problem in developing countries (Mahadevappa, 2012). In the same journal (Mahadevappa, 2012) it is also said gender bias led to paralyze society, due to discrimination that occurs on sex differences. Gender bias means a view that differentiates the roles, positions and responsibilities of men and women in family, community and development life. The male perspective in establishing women in films has helped to maintain a gendered society structure according to Akerman (in Abdullah et al, 2001). Women in social life are regarded as second class citizens so that their existence becomes not consideredin the patriarchal cultural system. As a result women will only become objects and lose rights in various areas of social life.

In this study discussed why women should be shown as men's desire. When women are constantly being shown as sex objects in online media especially instagram, men will unconsciously accept the justification in viewing that women are merely the satisfiers of men's sexual desires. Seeing the status of women who have always been viewed as a sex object of men, then the perception that there is a woman must appear and behave as an object of sex is a necessity (Hariyanto, 2009). Thus, self value and of women fall because they are only considered as a sex object. As a result, embedded the 
assumption that the main force of women is his body. Many mainstream media have a tendency to business by using this, as well as online media. They explore and exploit the women's sensual sideand make it into commodity. Online media uses women with their trademarked characteristics such as beauty, body elegance (breast, hips, and thighs). Online media can be accessed by anyone, in it sometimes also have interests like the mainstream media. The reality construction on the media either online or not is strongly influenced by the relationship of social forces that surround the media and its various pressures (Hariyanto, 2009).

Previous research discussed the media as a cultural agent and became the main instrument in shaping gender construction in society, in a journal by Hariyanto (2009) entitled Gender in Media Construction explaining how gender is displayed in media containing sexual harassment can bring old values, just as women are just as satisfied lust. The difference is that the research subjects used are mass media in general, while inthisstudy will use the internet media, especially Instagram.Gender bias theories needed in this study to see the imbalance that occurs with the role of women and men in online media. Online media generally show women are weak and oppressed by men.

\section{Semiotic of Charles Sanders Peirce}

Semiotics according to Peirce is logic, that is formal doctrine of sign (Budiman, 2011). Semiotic of Peirce sign or representamen is something that represents something can be an experience, a thought, an idea or a feeling. While something is called interpretant, which then refers to the object. Thus, a sign has a direct triadic relationship with the interpretant and object (Budiman, 2011). In the view of Charles S. Peirce, semiotics departs from three main elements, called triangle of meaning theory. Peirce presents three main elements, namely sign, object, and interpretant. The relationship of the three elements is described Peirce in the following picture:

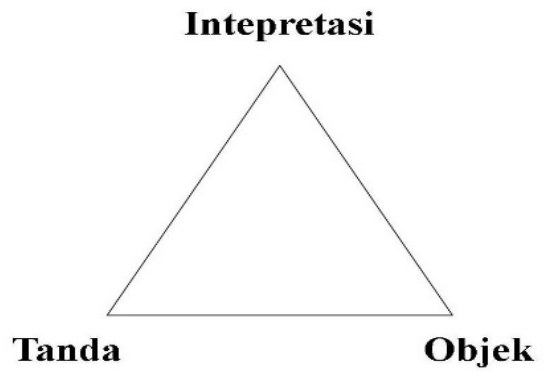

Figure 1.Triangle of Meaning

Sign is something that is physical that can be captured by the five senses and is something that represents another thing outside the sign itself. Sign based on the relationship with the object divided by Peirce into symbol (signs emerging from the agreement), icon (signs emerging from the physical representation) and index (signs arising from causal relations) (Marliana, 2013).

In previous research who raised the semiotics of Charles Sanders Peirce is Karima and Christin (2015) entitled Semiotic Analysis Charles Sander Peirce on Violent Presentation in the Little Krishna Cartoon Series Episode 5 September 2014. The similarity of research with this research is the method Charles Sanders Peirce's semiotics analysis, but the emphasis of the research is only the sign categories of icons, indexes, and symbols. In this study using semiotic theory because it is used to find the meaning of signsfrom the visual and text aspects.So, the results of the research analysis will be more profound. Various signs will be obtained from the various objects displayed in the upload image @ moduskeras.

\section{METHODOLOGY}

This research uses qualitative method with semiotic analysis approach. Qualitative research does not rely on the evidences based on mathematical logic, numerical principles, or statistical methods. Qualitative research aims at maintaining the form and content of human behavior and analyzing its qualities rather than transforming them into quantitative entities "(Mulyana, 2003).

Subjects in this study are some images uploaded by @ moduskeras account, researcher is trying to understand how gender of women be constructed based on visual and text aspectin the uploads. There 
are total of 10 images that will be the subject of this study. The images are chosen with consideration of the researcher that they will represent how thegender of women are formed in theuploaded images of@moduskeras account.

Semiotic can be defined as the study of objects or events through signs. Semiotic is used as a research method to define deeplyupon signs, because the object of research to be examined is related to visual and text signs (Farnisari \& Sudrajat, 2013). The semiotic method used by the researcher to know the gender constructs in the @ moduskeras account upload is from Charles Sanders Peirce.

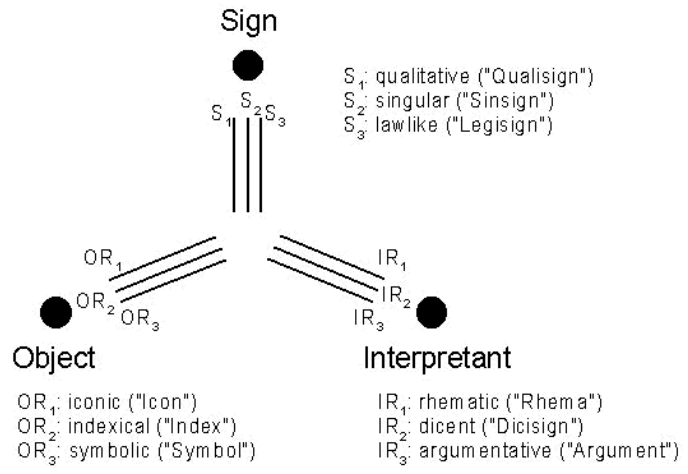

Figure 2.Triangle of Meaning with Classification

By knowing the classification of the sign relationships with the object, the researcher can reveal how gender is shaped in the presentation of the @ moduskeras image. This research emphasizes gender constructions on women, so the images chosen by the researcher are the images that visualize the women so it is clear that the sampling technique that researcher use is non-probability sampling. The researcher did not take the data source randomly because the researcher has certain considerations in choosing data sources. Researcher here use Purposive Sampling technique, because the sample taken must meet the criteria, requirements, and also the compatibility of the theory that must be determined by the researchers themselves based on the characteristics that have been determined (Given, 2008).

Researcher have taken the source of data in this study, there are 10 images from total of 1,358 population. Researcher tried to examine only images from @ moduskeras, because in images uploaded by @moduskeras the signs look obviously. While in the video uploaded by @moduskeras, the sensuality and sexuality of women displayed are very explicit based on the researcher. Instagram also has strict rules on the content to be uploaded. When a negative content upload too explicitly, it will be deleted by the system (Olzanowski, 2014). So, researcher is reluctant to examine further about video from@moduskeras. In qualitative research only needs a little sample because it makes senses to estimate anything. Further, the goals of qualitative research are provided highly contextually and depth understanding about spesific phenomena which is well-suited to small sample sizes (Given, 2008). Because in the images contain elements that researcher need such as how women are displayed in the picture, how the atmosphere around, and how the text is written in the image. In semiotic analysis of images, factors such as poses, angles, and gazes are considered and when a caption or text is included, the overall meaning of the image may change (Nilsson, 2016). It encourages researchers to conduct a semiotic review of how woman gender is shaped in the upload image of the @ moduskeras account.

Collecting data to be done by researcher is to use documentation and literature study. In this study there are 10 images upload account @ moduskeras which became the primary data of research. While for secondary data in this research is obtained by documentation or data collection obtained from previous research documents, so that the data and the theories obtained not deviate too far. Literature study emphasizes the researcher to collect data from the literature and theories that can be used as research material in this scientific publication.

Technique of data analysis used in this research is semiotic analysis of Charles Sanders Peirce. With the basic theory the triangle of meaning by Pierce, the stages of analysis conducted by researcher are as follows: 
Page 118 The technique of data validity that will be used in this research is triangulation theory technique. Triangulation theory is a technique to test the validity of the data through the decoding of patterns, relationships, and include an explanation that emerges from an analysis to find a theme or explanation which will later be used as a comparison (Bungin, 2008). Bachri (2010) mentions in his journal entitled Convincing Data Validity Through Triangulation in Qualitative Research that triangulation theory is to use two or more theories to integrate. Data obtained from the analysis of 10 uploaded images of @ moduskeras account using Charles Sanders Peirce's semiotic will be collected and reanalyzed and combined with the gender construction theory, so as to present comprehensive results.

\section{DISCUSSION}

After see and reviewing more about @ moduskeras account which has 1358 uploads of images and videos, the researcher have set 10 images as research objects. To find the meaning contained in the upload images@moduskeras will be explained by finding the sign through the element of the picture @ moduskeras, the visual element and the text element. To facilitate the process of data analysis, coding done in this study is the grouping or categorizing the sign based on the relationship with the object, Peirce classify the sign into an icon, index, and symbol (Sobur, 2006). After the two aspects are fulfilled the signs and objects then the process of signifying meaning called semiosis, this is called Peirce as triangle meaning semiotics (Vera, 2015). Then the meaning resulting from the semiosis process is categorized back into the concept of gender construction. Categorization refers to Visual and Other Pleasure book by Laura Mulvey (1989). The researcher found out how the gender constructions of women in @ moduskeras uploads.

\section{Objectivication of Women's Body}

Male gaze is a term introduced by Mulvey in relation to the role of women in cinema tending to be sexually objectified and seen by male audiences, it is formed from the analogy of cameras as the eyes of men (Mulvey, 1989). Mulvey argues that cinematography perpetuates and legitimizes the patriarchal order in which men become active watchers and women become the object to be watched. Women who stand in a patriarchal culture as a marker for men, bound by a symbolic order in which men can undergo their fantasy and obsession through linguistic commands by forcing women to be bound in place as carriers, not makers, meaning (Mulvey 1989). In @moduskeras account uploads, women are displayed with minimal clothing, exploiting their body parts, aimed to raise the pleasure of a sexual fantasy of the object through images to followers.

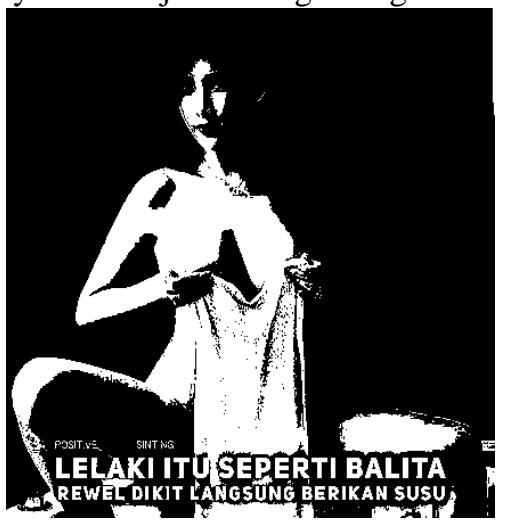

Figure 3

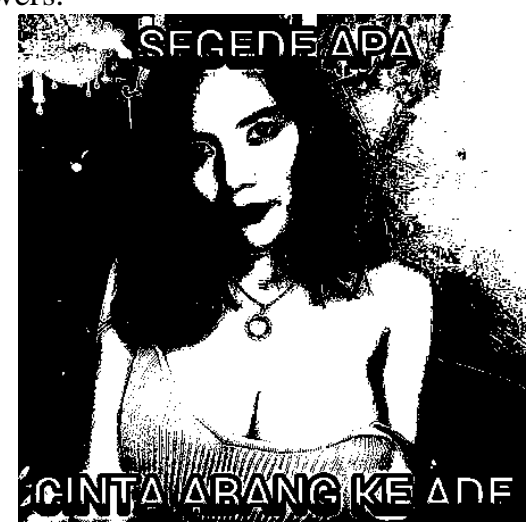

Figure 4 
The visual sign in figure 3 is a woman with brown hair while sitting. She is not wearing any clothes, her body is only covered by a white towel that she is holding with both hands in front of her body. She directly looks at the camera with a small smile on her face and an open legs position. The setting of placeseeing there are aspects of towels and faucets and looks like bathup, most likely the setting is in the bathroom. Angle of shoot is eye level with medium longshot technique. On the text sign it says " LELAKI ITU SEPERTI BALITA REWEL DIKIT LANGSUNG BERIKAN SUSU" is written with a white sans serif type with a vaguely red colored contour. In figure 4, the visual sign is a black haired woman, staring directly at the camera with a little smile. Wearing a yellow-colored dress but the clothes hook on the left descends to the upper arm. The setting is in the room looking at the red-colored sofa where she sits and the flash reflection from the camera behind her. Technique of shooting close up, with eye level angle. "SEGEDE APA CINTA ABANG KE ADE" is a text sign aspect written in yellow colored sans serif type and has a color gradation to orange, with a black outline.

The women in both images become icon, the place background and the woman's gaze become the indexical on the two images. The symbol in figure 3 are "LELAKI" and "BALITA" referring to human's sex and human growing phases. An equation exists between men and toddlers, then this refers to a metaphor of childishness. The symbol of childishness is also shown by the word "REWEL DIKIT". The position of the hand holding the towel over the chest and "BERIKAN SUSU" is an indexical sign. In figure 4, the symbolic aspect also appears as a male and female representation of "ABANG" -big brother-and "ADE" -little sister-, in married Indonesian society, the substitute of nicknames to the couple may be Mas, Kangmas, Adik, Dik, called as Mas usually refers to the male as the head of the family and vice versa. Both images have the same points on the emphasized body part of the breast. Breasts can be an iconic symbol and a metaphoric symbol of body elegance and women sexuality (Hariyanto, 2009). In the figure 4, the text "SEGEDE APA" becomes a symbol for the appropriate meaning, "SEGEDE APA" refers to the size of woman breasts because there is a visualization of woman with a downward shirt showing the cleavage.

The interpretation of figure 3 is that men are portrayed as childish and only sexual activity can ease them. Woman associate with sexuality, portrayed with their body elution especially breasts. This indicates that women are used as object of male gaze and sexual fantasies (Mulvey, 1989). Similarly, in figure 4, the part of the body that is often exploited for male sexual fantasies is a half-open woman breast. With parts woman's body exploited in such a way, the @moduskeras followers will arise enjoymentwhich obtained when looking at pictures of other people's bodies. Visual enjoyment or scopophilia is usually understood as something of erotic pleasure acquired when looking at others body (Handayani, 2017).

In both posts the women become passive object that is seen. Mulvey says cinema offers some pleasures one of which is scopophilia. Departing from the thought of Sigmund Freud that associates scopophilia against women as objects, subjugating them to a controlling and curious gaze (Mulvey, 1989). Pleasure in seeing is split into between active or male and passive or female. The male gaze determines and projects his fantasies into the female figure, which is made accordingly. Women who were used as sexual objects were the main theme of the erotic spectacle (Mulvey, 1989).

\section{Commercialization of Women}

Women become objects that saleable to be watched. Women are simultaneously an object that is viewed and displayed, with a strong visual appearance and a strong erotic level so that women are associated with something to be viewed with the intent to satisfy the curiosity of men (Mulvey, 1989). In @ moduskeras upload, women displayed into the object image, sensuality of women wrapped in such a way that led to highlighted some parts of the women's body to be enjoyed followers @ moduskeras account. 


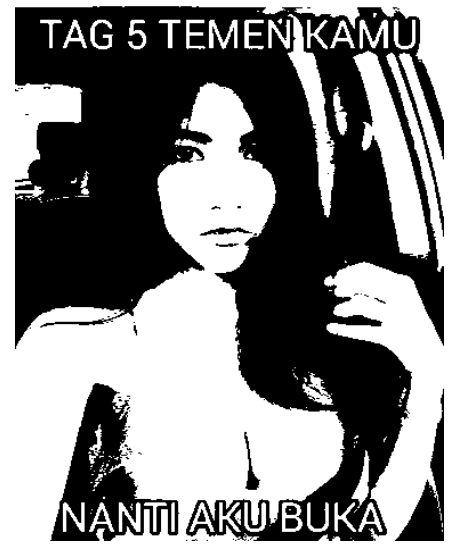

Figure 5

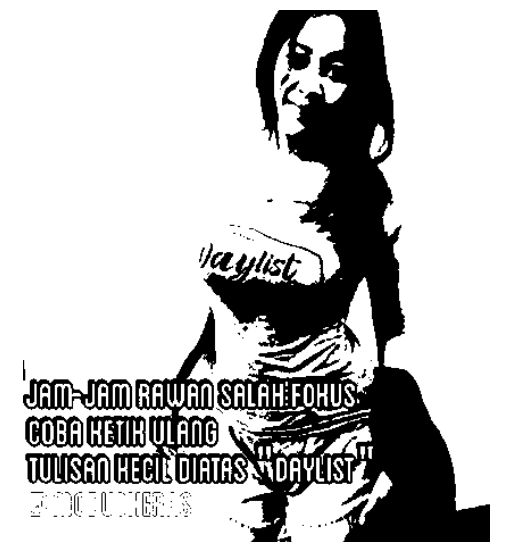

Figure 6

In figure 5 has a visual sign of a woman sitting in the car, wearing a pink shirt. The woman poses look straight at the camera with the position of the lips known as the "duckface", the position of the woman's left hand resting on her loose hair near her left shoulder. The upper body-the woman's breasts- are slightly visible. Seen also car seatbelt across his body. The shooting angle is parallel to the eye and the shooting technique is close up. The text aspect is TAG 5 TEMEN KAMU NANTI AKU BUKA, written in capital letters type yellow colored sans serif with orange outline. In figure 6 the visual sign is a woman posing smiling while standing in front of a white wall wearing a tight bluecolored T-shirt that read "Daylist" and brown shorts to show the curves of her body, the view of women toward the camera. The shooting angle is eyelevel with medium long shot technique. On the text sign it reads "JAM-JAM RAWAN SALAH FOKUS COBA KETIK ULANG TULISAN KECIL DIATAS DAYLIST". Written with sans serif type, has a white graded yellow with black outline.

The women in both images are iconic sign, hand poses in figure 5 being the indexical sign along with the mark on the text aspect of "TAG 5 TEMEN KAMU NANTI AKU BUKA" so meaningful by giving a sign -to mention other people-in the post, then the woman will open something. The only symbolic sign in figure 5 is the lip pose known as "duckface" and a pink colored outfit, the two symbols representing the femininity (Forsman, 2017). In the figure 6 indexical aspect is text which reads " JAM-JAM RAWAN SALAH FOKUS COBA KETIK ULANG TULISAN KECIL DIATAS ", while the symbolic sign is on the word "DAYLIST" on the text aspect referring to the visual aspect of the blue shirt worn by women, tight shirts are also a symbolic sign for sexiness (Mulvey, 1989). The distance and shoot technique in figure 6 become an indexical sign which aims to show woman's curves.

The interpretation that appears in figure 5 is that the woman body can be enjoyed if the post is disseminated by mentioning others in the upload, in other words the @ moduskeras account owner uses women sensuality to be commercialized. Similarly, in figure 6, instead of regretting the focusing hours, the @ moduskeras invites his followers to rewrite the word above "DAYLIST" which in reality is unreadable, it actually raises scopophilia voyeurism to the shape of women's curves. The curiosity that blends with the fascination and recognition of the sensuality of the woman body (Mulvey in Handayani, 2017).

In both uploads, Women are shown as commercialized object, in other words by showing the women' sensuality of @ moduskeras account gain the benefits like popularity, in which if images from @ moduseras are shared by other Instagram users, its follower willincrease or even become mean for advertisement of certain products. Women are only considered as objects, decorative functions. Motivation to make women as objects caused by the construction of women sensuality that surrounds her body (Handayani, 2017)

\section{Women Become Objects of Fetishism and Being Passive}

Fetish, according to Freud as a substitute for the imaginary vision of the woman's castration with a particular and often shocking object, which represents the lost phallus but has no direct relation to it. For the fetishes, the substitute objects will be subjected to them as a source of sexual fantasy and in every sign stand for phallus / penis (Mulvey, 1989). 
Vol. 10 No. 2

November 2018

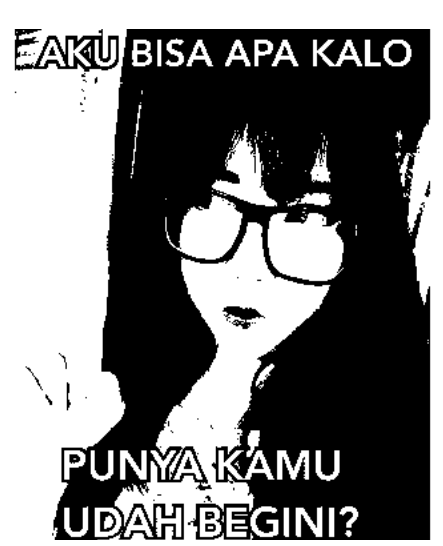

Figure 7

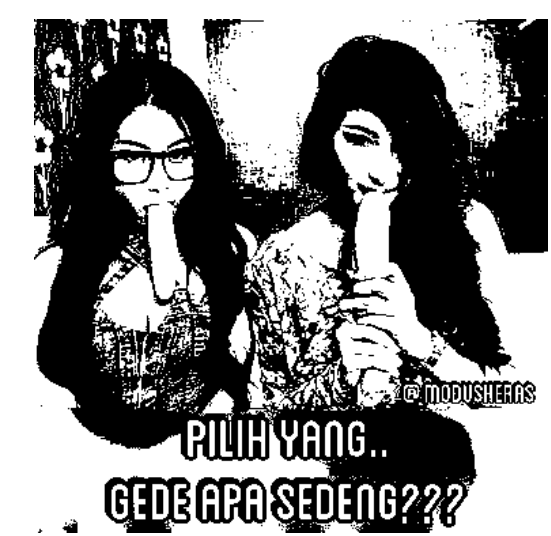

Figure 8

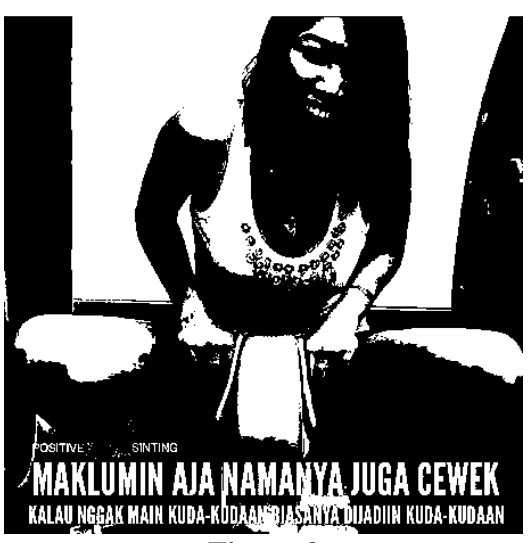

Figure 9

Figure 7, the visual sign is woman wearing glasses with loose hair. Posing with facial mimic known as "duckface" followed by staring towards the right forefinger that she raised at outdoors background. With the portrait position, the shooting angle is eye level and close up technique. For sign of text aspect " AKU BISA APA KALO PUNYA KAMU UDAH BEGINI?" Is written in whitecolored sans serif type with black outline. In figure 8, there are 2 adult women, one wearing glasses while the other is not. Clothes worn by the glasses is probably the type of frog jeans and the other is sabrina with flower motifs. The striking signs are the two women shown with other objects, banana and cucumber. The second position of the object is a banana held by a woman with glasses with his mouth, while cucumber held by another woman with two hands and cucumber placed attached to his mouth. The background of the image is in the room because it looks behind 2 women there is a white object that most likely is a mattress. The angle of shooting is parallel to the eye with medium shot shooting technique. The text aspect sign " PILIH YANG GEDE APA SEDENG??" Was written with a yellow colored sans serif type with clear black outline. The visual signs shown in figure 9, a woman sitting on a toy horse wearing a white tanktop, open leg position, and showing an expression of excitement. The shooting angle is parallel to the eye and with medium long shot taking technique so that most of the photo objects are seen as a whole. On the text aspect " MAKLUMIN AJA NAMANYA JUGA CEWEK KALAU NGGA MAIN KUDA-KUDAAN BIASANYA DIJADIIN KUDA-KUDAAN" -written with sans serif type and white colored that have pink outline.

From the three images above, there are similarities of iconic signs of women form, shown by light skin, straight-haired and posing section women. In figure 7 there are 2 elements of the iconic and symbolic signs that are very clear and visible, the forefinger of woman and the word written "PUNYA KAMU", the two visible signs refer to the male's genital. In figure 8 , there are 2 iconic signs of banana and cucumber. The forefinger, banana, and cucumber in this context replace the figure of the phallus/penis (Mulvey, 1989). Another available sign is the woman with glasses in figure 7 with a glance of the eye toward her forefinger and the duckface expression. In the context of society, people 
with large glasses are known as smart but innocent. The symbolic sign that appears is plain, in this context plain becomes more suitable. The indirect position of the eye toward the camera becomes an indexical sign of the woman's shy figure in expressing her thoughts (Wahyuningtyas, 2015), or also as a form of muttering-something unspeakable-with a condition relating to the male's genital which is indicated by the text "AKU BISA APA". Forefinger be indexical and also as a symbolic sign because of its "pointed" position and the text of "UDAH BEGINI" so that it can be interpreted as male desire

Page 122 or lust (Mulvey, 1989). In figure 8, the indexical signs are obtained from the gaze of the two women toward the camera, with a slight bend to make a seductive impression (Apsari \& Widiatmoko, 2010). The symbolic sign is also shown by the difference in size between the banana and the cucumber which means there is a difference in the size of the male's genital. It is supported by GEDE ATAU SEDENG text, which refers to both objects. The background at the room- can be said to be an index of which is approximately the place where sexual desire is channeled (Mulvey \& McCabe, 1989). Figure 9, the indexical sign shown by " MAKLUMI SAJA NAMANYA JUGA CEWEK" indicates women must be tolerated because of the comparison of activityshe does with her usually "becomes" the object, the word "CEWEK" as symbol of representation of women. Horse toy became a clear icon and became a symbol associated with the text "MAIN KUDA-KUDAAN" and "DIJADIIN KUDAKUDAAN". From the relationship of these symbols can be interpreted that women become object as horse in another word become a sexual object. Everything is centered on men, women only as objects of the male fetish who see what women carry or display is a representation of the phallus (Mulvey, 1989).

The interpretation, women are plain and shy in denying or asking for her sexual needs. In the post of @ moduskeras figure 7, women are described as being who can not resist the will of men. Women are described as passive, they can not start the activities if men didn't take the initiative first. The presence of men is necessary for the role of women to work (Damayanti, 2014). In the picture of 8 women despite being faced with option matter of size, they still want to come into contact with both. It means that women can not choose, women shown to remain the same nature, that is want, regardless of the size of a phallus. It requires that women in @ moduskeras account uploads be passive (Mulvey, 1989), who accept whatever men so their desires are fulfilled. Figure 9 The portrait of women becomes a "tool" of men sexual satisfaction and it is said by @moduskeras as a thing to be tolerated.

In the three uploads of @moduskeras, women are described as passive and can not choose and become fetish objects of men. Mulvey (1989) says women with phallus will be seen to have glory, women without the presence of phallus is nobody. The presence of women is always accompanied by the presence of a phallus figure, if there is no figure of the phallus then the women will be punished and humiliated, and women are shown as the phallus itself (Mulvey, 1989).

\section{Women Have Limits and Imprisonment from The World}

In the analysis of several films by J. L. Godard - Pierrot le fou and Une femme mariee, Mulvey and McCabe found indications that the women featured had a limit. The use of interior space in the film is intended to limit women's dreams to the world. The spatial limitations introduced by women's point of view have no relation to 'realism', but Godard uses this diminished space to analyze women relating to his social formation, home. (Mulvey \& MacCabe, 1989). Godard never shows women placed in economic or social roles that are not an aspect of their sexual function or social rationalization. It is as if women can only be interested in their sexuality (Mulvey \& MacCabe, 1989). In @moduskeras posts, women are also often displayed as a figure who only deals with homework and sexual activity. 
Vol. 10 No. 2

November 2018

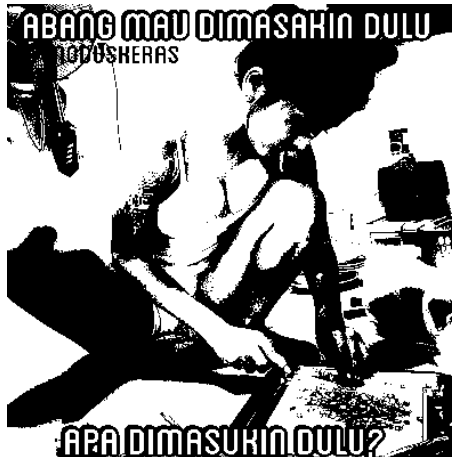

Figure 10

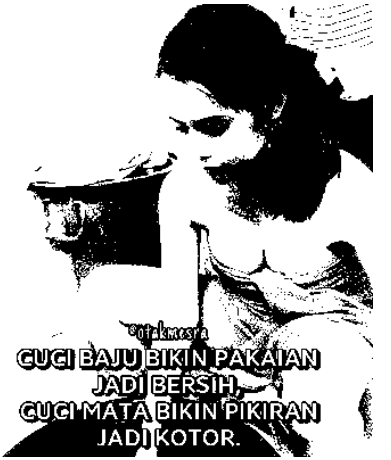

Figure 11

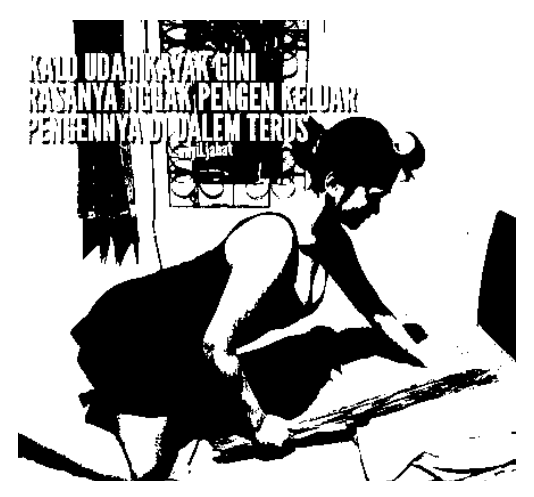

Figure12

In figure 10, the visual sign is a woman with her hair tied while looking down, dressed in minimal white-colored, squatting while chopping vegetables with a knife. The background image when it is associated with activities that women are doing then most likely the room is part of the kitchen. The shooting angle because the woman is looking down is a high angle with a shoot technique using medium long shot. For the text sign "ABANG MAU DIMASAKIN DULU APA DIMASUKIN DULU" written in white sans serif type font with black outline. In figure 11, the visual sign of a woman with ponytail-tied hair, wearing a brown colored cloth wrapped around her body. she is washing, from the visible object it can be ascertained the background of this image is in the bathroom, the position of the right hand and the gaze of the woman fixed on the black bucket. The angle of shooting is high angle with medium shot technique. The text sign is written " CUCI BAJU BIKIN PAKAIAN JADI BERSIH, CUCI MATA BIKIN PIKIRAN KOTOR" with a white colored sans serif type with black outline. Figure 12, the visual sign is a woman wearing a black colored minidress with hair wearing a roll. Activities that women are doing is cleaning or arranging the bed. The position of woman is on all fours while the right hand holding a broom stick. The background of the place is on the mattress that indicates the bedroom. Technique and angle of shot are medium longshot and high angle. The text sign is" KALO UDAH KAYAK GINI RASANYA NGGA PENGEN KELUAR PENGENNYA DI DALEM TERUS" written in white sans serif type without outline.

Women on the three images above are iconic signs, women who are doing something in @ moduskeras shown tend to be light skin, tied hair and using minimum clothes so part of their body is visible. Background place, tied hair and minimum clothing on the three images above become indexes, because have relation to hot temperatures obtained during activity inside the room. As for the third pose of women above also become indexes, in relation they are doing something. In Figure 10 the visual aspects of women cutting vegetables with knives and "ABANG", "DIMASAKIN" and "DIMASUKIN" text aspects become a symbolic sign that in Indonesian society, women have an obligation to serve men such as grooming, cooking, and giving birth. In figure number 11 the indexicalsigns are all aspects of the text sign, indicating the cause and effect. However, there are symbolic signs in it, which are indicated by "CUCI BAJU" and "CUCI MATA" each representing a 
washing and sight-seeing activity. The "CUCI MATA" context here means seeing something that can awaken libido-like the image of a washing woman wrapped in a cloth only-indicated by the indexical sign of "PIKIRAN JADI KOTOR". In Figure 12 another iconic sign is a broom stick that represents the phallus (Mulvey, 1989). The text aspect in figure 12 becomes an indexical sign. From the overall textual and visual aspects of figure 12 there is a relation of the incidence of male libido to women when women pose on all fours and its existence on the bed (Mulvey \& McCabe, 1989). Of the three

Page | 124 images there is a similarity of indexical sign, the gaze of women who are looking down without the slightest bit towards the camera shows helplessness (Wahyuningtyas, 2015).

Interpretation that appears in the images above are in the picture 10 women can offer only two options to men that is cooking or having sex, in pictures 11 and 12 women are described doing other homework but become the sexual object of men in the end. Women in a patriarchal culture have an obligation to do in the home, especially women who have been married. They will only socialize in limited social environment, doing the same activity repeatedly, don't have any chances to develop themselves and their personalities (Siswati, 2014). Women undergo domestication and subordination so that women's work is in the form of additional assistance (such as cooking, cleaning) to alleviate the work of men (Sutarso, 2011). The angle of shooting and the women's gaze on the three images symbolizes the powerlessness of women in paying attention to the demands of the outside world, so as to imprison women in their lives (Mulvey \& MacCabe, 1989).

In the three uploads of the @ moduskeras account, women are shown as a figure who only deals with the home environment, and all three also share the same context in sexuality. In another analysis of Godard's movie Deux ou trois chases que je sais d'ell, Mulvey and MacCabe say women are increasingly tied to homes and cameras echo their imprisonment. The beds evoke more intimate but more limited space, the comfort zone in the prison, yet at the same time bringing back to important associations between women and sexuality (Mulvey \& MacCabe, 1989).

\section{CONCLUSION}

The @moduskeras account shows and constructs women in their images post according to the four categories described. In the 10 images, women are constructed as people who can be objectified body, commercialized, become the object of fetishme, and have limits. Body objetivication refers to women being the object of a male gaze so that her body parts become male sexual fantasies. Commercialization is related to in addition to being watched, women's bodies are also on display that elicits men's curiosity, women are considered decorations that can bring benefits because of their sensuality. Women are represented as objects of fetishme in which every sign represents the phallus symbolizing glory, and women are considered to have no power because they are without phallus, making themselves into nobody then become as passive figure. While women are also shown to have limits and imprisonment, the @moduskeras account describes women who only struggle in homework and sexuality affairs only. Finally, the entire category can be used as a reference to see and know how@moduskeras account has constructed the gender of women in its upload. Following this research and previous research about gender constructions, researcher hope that many future studies will examine how gender shifts amid the rapid flow of new media developments. Because we know, gender also changes with the development of technology and information.

\section{REFERENCE}

Abdullah, Irwan et al. 2001. Bias Gender Terhadap Penanganan Kasus Kekerasan Terhadap Perempuan Secara Ligitatif. ISSN: 0853-0262.

Cahyono, Anang Sugeng. 2016. Pengaruh Media Sosial Terhadap Perubahan Sosial Masyarakat di Indonesia.

Apsari, Diani. Widiatmoko, Didit. 2010. Visualisasi Wanita Indonesia Dalam Majalah Pria Dewasa. 65-79. Jurnal Komunikasi Visual \& Multimedia. Vol. 2. No. 1. Tahun 2010. Institut Teknologi Bandung.

Arif, Ahmad Fadli. 2017. Analisis Sikap Narsisme Dalam Aplikasi Instagram.

Bachri, Bachtiar S. 2010. Meyakinkan Validitas Data Pada Penelitian Kualitatif.

Boyd, Danah M. Ellison, Nicole B. 2008. Social Network Sites: Definition, History, and Scholarship. Journal of Computer-Mediated Communication 210-230 International Communication Association. 
Damayanti, Lestari I. 2014. Konstruksi Gender Dalam Citra Visual Pada Buku Teks Untuk Siswa Dasar. Indonesian Journal of Applied Linguistics, Vol. 3 No.2, January 2014, pp. 100-116.

Marliana, Sekar Dwi. 2013. Identitas Seksualitas Remaja dalam Film (Analisis Semiotika Representasi Pencarian Identitas Homoseksual oleh Remaja dalam Film The Love of Siam). KomuniTi, Vol. V, No. 2 September 2013. Universitas Muhammadiyah Surakarta.

Kurniawati, Wenday Dwi Novi. 2016. Pemanfaatan Instagram oleh Komunitas Wisata Grobogan dalam Mempromosikan Potensi Pariwisata Daerah. Komuniti, Vol. VIII, No. 2, September 2016. p-ISSN: 2087-085X, e-ISSN: 2549-5623. Universitas Muhammadiyah Surakarta

Farnisari, Megaria. Sudrajat, Arief. 2013. Bias Gender Dalam Film Seri Korea "Sungkyunkwan Scandal" (Studi Semiotika Kesetaraan Gender Dalam Pendidikan) . Universitas Negeri Surabaya.

Forsman, Michael. 2017. Duckface/Stoneface: Selfie Stereotypes and Selfie Literacy in Gendered Media Practices in Sweden.

Handayani, Rivi. 2017. Male Gaze dalam Fotografi Model: Objektifikasi dan Komersialisasi Tubuh Perempuan. Jurnalisa Vol 03 Nomor 1/ Mei 2017.

Hariyanto. 2009. Gender Dalam Konstruksi Media. Purwokerto: Komunika, Vol.3 No.2 JuliDesember 2009 pp.167-183. ISSN: 1978-1261.

Judhita, Cristiany. 2015. Gender dan Seksualitas dalam Konstruksi Media Massa.

Judhita, Cristiany. 2015. Meme di Media Sosial: Analisis Semiotik Meme Haji Lulung. Jurnal Pekommas, Vol. 18 No. 2, Agustus 2015: 105 - 116.

Karima, Salyla. Christin, Maylanny. 2015. Analisis Semiotika Charles Sander Peirce Atas Presentasi Kekerasan Dalam Serial Film Kartun Little Krishna Episode 5 September 2014. ISSN : 2355-9357.

Karunianingsih, Dyah A. 2016. Kamera Sebagai Alat Operasi Male Gaze: Analisis Male Gaze dalam Film Horror "Pacar Hantu Perawan".

Lay, Taylor. 2018. The Construction of Gender in Contemporary Magazine Advertisement. Department of Communication. University of Ottawa, Canada.

Mahadevappa. 2012. Gender Bias and Social Justice. IOSR Journal of Humanities and Social Science (JHSS). ISSN: 2279-0837, ISBN: 2279-0845. Volume 4, Issue 2 (Nov. - Dec. 2012), PP 4244.

Nillson, Malin. 2016. "First Let Me Take Selfie" Young Adult Self Representation on Instagram. MA Media and Communication. Malmö Högskola.

Olszanowski, Magdalena. 2014. Feminist Self-Imaging and Instagram: Tactics of Circumventing Sensorship. Visual Communication Quarterly, 21:2, 83-95.

Puspitorini, Dyah Ayu. 2013. Motif dan Kepuasan Penggunaan Instagram (Studi Kesenjangan antara Motif dan Kepuasan Penggunaan Media Sosial Instagram pada Mahasiswa Universitas Muhammadiyah Surakarta Angkatan 2013).

Shaista Irshad and Prof. Dr Niroj Banerji (2012). Gender as Social Construct in Margareth Atwood's Oryx and Crake. ISSN-L: 2223-9553, ISSN: 2223-9944 Vol. 2, No. 2, March 2012. Department of Humanities and Social Sciences, Motilal Nehru National Institute of Technology, India.

Siswati, Endah. 2014. Representasi Domestifikasi Perempuan dalam Iklan. Jurnal Ilmu Komunikasi. Vol. 11, No. 2, Desember 2014.

Sutarso, Joko. 2011. Konstruksi Isu Gender Dalam Politik: Studi Kasus Pemilihan Umum 2004. KomuniTi, Vol. II, No. 2, Januari 2011.

Wahyuningtyas, Dita. 2015. Peran Gesture (Gerak Tubuh) Guru Sebagai Upaya Menumbuhkan Perhatian Siswa Pada Pembelajaran Pendidikan Agama Islam di Sekolah Menengah Kejuruan Ketintang Surabaya.

Yulidya, Sisca. 2014. Konstruksi Gender Pada Tokoh Minions dalam Film Despicable Me 2.

Zubaidi, Advan Navis. 2011. Ruang Publik Dalam Media Baru (www.kaskus.us). Jurnal Ilmu Komunikasi, Vol. 1, No.2. ISSN: 2088-981X.

Book and e-book:

Alex sobur. 2006. Semiotika Komunikasi. Bandung : Rosdakarya.

Antony, Mayfield. 2008. What is Social Media?.

Budiman, Kris. 2011. Semiotika Visual ; Konsep, Ilmu, dan Problem Ikonisitas. Yogyakarta : Jalasutra. 
Flew, Terry. 2004. New Media An Introduction.

Given, Lisa M. 2008. The SAGE Encyclopedia of Qualitative Research Methods. Vol 1 \& 2. ISBN 978-1-4129-4163-1

Mulvey, Laura. 1989. Visual and Other Pleasure. ISBN 978-0-333-44529-7 ISBN 978-1-349-19798-9 (eBook) DOI 10.1007/978-1-349-19798-9.Published by PALGRAVE Houndmills, Basingstoke, Hampshire RG21 6XS and 175 Fifth Avenue, New York, N.Y. 10010.

Page|126 Mulvey, Laura. 1975. Visual Pleasure and Narrative Cinema. Film Theory and Criticism : Introductory Readings. Eds. Leo Braudy and Marshall Cohen. New York: Oxford UP, 1999: 833-44.

Mulyana, Deddy. 2003. Metodologi Penelitian Kualitatif. Bandung : Rosdakarya.

Vera, Nawiroh. 2015. Semiotika Dalam Riset Komunikasi. Bogor : Ghalia Indonesia

Zarella, D. 2010. The Social Media Marketing Book. Jakarta : PT. Serambi Ilmu.

Internet :

https://www.statista.com/statistics/253577/number-of-monthly-active-instagram-users/ _ - diakses tanggal 18 Mei 2017.

www.instagram.com/about/faq - diakses tanggal 18 Mei 2017.

http://file.upi.edu/Direktori/FIP/JUR._PSIKOLOGI/196605162000122-HERLINA/IP-

TM11_PENAMPILAN_FISIK_DAN_PENGGUNAAN_BENDA.pdf - diakses tanggal 17 Februari 2018

https://get.simplymeasured.com/rs/135-YGJ-288/images/2017_1-Ultimate-Instagram_eBookFinal2.pdf - diakses tanggal 13 Februari 2018

http://www.desainstudio.com/2010/04/pengertian-serif-dan-sans-serif.html - diakses tanggal 18 Februari 2018

http://www.kelasfotografi.com - diakses tanggal 18 Februari 2018 